Yuliia ORLOVSKA, Khrystyna DRYHOLA

\title{
INTERNATIONAL INTELLECTUAL ECONOMY: PECULIARITIES OF DEFINITION AND EVALUATION IN THE CONTEXT OF SUSTAINABLE DEVELOPMENT
}

\begin{abstract}
The issue of the definition of the intellectual economy is investigated. The essence of knowledge economy and knowledge-based economy is defined, the similarity and difference of the categories are formulated. The approaches of western and national scientists to the peculiarities of the definition of an intellectual economy are analyzed. The connection of the intellectual economy with the concept of sustainable development as a priority trend is established. It is established the essence of the intellectual economy and its main participants that form the structure of the world intellectual economy. The factors that influence on the intellectual economy through the usage of international indexes are investigated. They characterize the activity of each participant of this system. The approach to the estimation of the world intellectual economy condition based on the integral index of the intellectual economy is proposed. It consists of five international indexes that are brought about to a single coordinate information system. The ex-
\end{abstract}

(C) Yuliia Orlovska, Khrystyna Dryhola, 2018.

Orlovska Yuliia, Doctor of Economic Sciences, Professor, Prydniprovska State Academy of Civil Engineering and Architecture, Dnipro, Kyiv.

Dryhola Khrystyna, PhD student, Prydniprovska State Academy of Civil Engineering and Architecture. Dnipro, Ukraine. 
pert estimation method was used in determining the weighting coefficients of each international index in the integral index of the intellectual economy. The integral index of the intellectual economy has been calculated for certain formation centres of the structure of the intellectual economy: the USA, Japan, Poland, China, India, Russia and Ukraine. The expediency of further participants' research and structure of the world intellectual economy is substantiated.

\section{Key words:}

Intellectual economy, knowledge economy, intellectual economy estimation, sustainable development.

JEL: F01, F20, F29, 057.

\section{Introduction}

The modern development stage of the international economic system is characterized by intensification of the use of intellectual capital. At the same time information and knowledge have the role of the main product and the main resource of the modern economic system, and by this means the notion intellectual economy has arisen. In terms of which the pace of creation, dissemination and use of information is speeded up. In the context of the new system, new principles and laws of economic development, new forms and structures are formed, and new world centers of influence arise. All these features radically change the modern international economic system. The basis of it is the intellectual economy, which in research has many synonymous definitions, and requires its systematization and generalization. In addition, it is important to understand both the participants in the global intellectual economy that shape its structure and the factors that influence on its development, which in the theoretical and methodological plan will form the basis of the regulatory system of sustainable development and information society. 


\section{Analysis of the recent research and publications}

From the end of the nineteenth century scientists began analyzing knowledge and information as a factor of production and the basis of the economic system. During the evolution period of categorical apparatus, such terms as knowledge economy, knowledge-based economy, new economy, modern economy, intellectual economy were used. A lot of scientists use these terms without a tangible difference between them, they just replace one upon the other. Nevertheless, the basis of these concepts is the same - knowledge, there is a difference in the essence of these terms.

A. Marshall a well-known economist, embodied the general understanding of knowledge as the basis of the new economic system. He defined (Marshall, 1890): "Knowledge is our most powerful engine of production». During that period scientists began to realize that it is information itself, knowledge itself are the basis for economic development. (Schumpeter, 1911) defined a special combination of knowledge as the basis for innovation, which is the driving force of production. The notion of the knowledge-based economy was formed in the 19501960s. (Druker, 1950) and (Machlup, 1962) explored the industrial society and the industrial economic system in their theses. With that they focused their attention on the nascence of so-called innovative industries. Knowledge or information was the main basis. Thus, for the first time, the very essence of the new structure of the economy was displayed and the category knowledge economy has appeared. That is a sector of the economy that includes economic activity based on the use of knowledge. Under the end product it has new knowledge or a particular informational product or service. (Machlup, 1962) focused on such areas as education and science, the areas where the intellectual product is produced, and the field of intellectual services and media, where the product is distributed through. And in this period the concepts of knowledge economy and knowledgebased economy are deeply interwoven.

As (Ivanova, 2011) mentions, these notions are different. Knowledgebased economy is a type of economic system that reflects the essence of postindustrial society. It means that it is based on the knowledge and information provided in all sectors of economic activity. Conversely, knowledge economy is a denotation of the economy sectors that specialize in obtaining an intellectual product.

However, for a long time, scientists did not consider knowledge and information through the prism of the production function. (Skilbeck, 1964) and (Abramowitz, 1956) consider knowledge as a human factor or technology change, but do not consider knowledge and information as a separate factor. (Romer, 1986) changed the perception of this concept. He began to take into ac- 

and Evaluation in the Context of Sustainable Development

count knowledge as an important factor of production, in other words, the basis of knowledge-based economy.

Until the 1990s, the categorical apparatus was not clearly formed. The Organization for Economic Cooperation and Development (OECD, 1996) did the first attempt to define the category knowledge-based economy as one that has in its essence the focus on the production, distribution and use of knowledge or information. (APEC, 2000) provides the similar interpretation.

With the technology development, the categories Knowledge economy and Knowledge- based economy have been including the IT sphere, which has been used inseparable with these terms. (Chartland, 2006) introduces three key concepts knowledge, network, and innovation into Knowledge Economy. (Brinkley, 2006) is considering the knowledge economy inseparably with the IT sector. He claims that the concept of the structure of such economy is the combination of highly skilled workers who are aware of knowledge and information technology, who ultimately create an intellectual product. As (Tapscott, 2014) mentions, another important aspect that comes from the IT-industry is virtualization of the economy.

(White, Gunasekaran, Ariguzo, 2012) make an extension of the interpretation of the economy structure of a new type. Scientists supplement the economy structure with such concepts as education, knowledge management and creativity, in addition they emphasize that all components of the economy structure are based on IT-technologies.

UN experts (Huggins, Izushi, Prokop and Thompson, 2014) add 2 elements to the above-mentioned concepts: competitiveness and economic growth. That means that knowledge-based economy is an economic system that creates, distributes and uses knowledge (information) to ensure economic growth and international competitiveness of countries.

Since the 70 s of the twentieth century along with the processes of informatization, computerization and enhancement of the role of knowledge, the process of reorientation of the economic system to the path of sustainable development is taking place. This definition was formulated by the Brundtland (World Commission on Environment and Development, 1987) in the report «Our Common Future». Sustainable development is defined by the type of development that meets the needs of the present generation without compromising the ability of future generations to meet their needs. Therefore, it is advisable to consider the intellectual economy in the context of sustainable development that is a global trend and a post-industrial paradigm.

As (Shahrazad, 2017) mentions, information as an expression of knowledge becomes the driving force of the knowledge economy that is based on human, intellectual and social capital in the context of increasing the role of creativ- 
ISSN 2519-4070

ity of the economy. This is considered as a key aspect in building a long-term strategy for sustainable development of the country.

The research of the problems, the essence and structure of the knowledge economy are devoted to the works of modern Ukrainian scientists. (Gaponenko, 2010) notes that any economy that creates, distributes and uses knowledge for growth and competitiveness is a knowledge economy. Consequently, following this definition, such type of economy is not only about modern system but it is also about ancient system. (Fedulova, 2009) emphasizes the fact that this type of economy is more specialized in the creation of a high-intellectual product than simply the use of knowledge. (Azhazha, 2007) notes that it is the uniqueness of peoples' skills and their intellectual capital form the basis of the modern knowledge economy. (Androschuk, 2006) asserts that first of all the knowledge economy is a system aimed at minimizing interference in the ecosystem of the planet. And correspondingly, causes minimal damage to nature and has to change the economic system of the extensive type that is aimed at satisfying the needs and material enrichment of nations. These thoughts are the foundation of the concept that the knowledge economy should not be the only basis of the modern economic system, but also it should have a link with the concept of sustainable development.

It should be noted that in spite of significant scientific achievements concerning the formation of the categorical apparatus foundations of the modern intellectual economy, the analysis of its essence, the question of determining the factors of formation of the world intellectual economy requires an additional research, as well as evaluating the factors of influence on its structure. That is why the purpose of this work is to identify the main participants in the world's intellectual economy and assess its status by evaluating the factors of influence on the formation of its structure.

\section{Presentation of the main research material}

Analyzing the work of scientists, it can be affirmed that the term intellectual economy embodies the connection between categories of knowledge economy, knowledge-based economy, and sustainable development. In our opinion, the intellectual economy is a type of economic system that relying on the intellectual capital of a society in the development of modern information technologies and systems, uses, transforms, creates and disseminates information and knowledge in order to ensure the country's international competitiveness within the concept of sustainable development. In other words, knowledge is at the heart of the economic system, and it is the ultimate product of this system, which influences the formation of the structure of the intellectual economy. 
To form the structure of any system, an understanding of the process is necessary. This is the essence of this system, its participants, and factors that influence the course of the process itself. On the assumption of our definition of intellectual economy, the main process within this system is the formation of a high-intellectual product that is based on the use and transformation of knowledge, applying information technology in the context of sustainable development. Consequently, the main participants in this process are:

- a workforce with certain knowledge and individual skills;

- modern technologies that take part in the process of information transformation

- communications (network), which form the basis of distribution of an information product

- the state as a guarantor of support and the intellectual product protection. It also has a role of the basis of the formation of a favorable environment for the development of the intellectual type of economy in different countries that together form the structure of the world's intellectual economy.

To determine the factors that influence the formation of the world's intellectual economy and its condition we offer to use international indices. They contain list of indicators that reflect the peculiarity of influence. The components of each index that can be considered as factors that impact the formation of the structure of the world's intellectual economy; whereby it is possible to assess the condition of the system itself.

1) In order to evaluate the workforce in the context of the intellectual economy, we offer to use the Human Development Index (HDI).

The key factors of influence are:

- Lifetime

- Education expectancy

- The average length of education

- The standard of living expressed as per capita GNI per purchasing power parity.

2) To evaluate modern technology, we offer to use the NRI (Networked Readiness Index). This index evaluates the information environment in terms of readiness, usage, impact and features of the environment itself. Each of the factors is estimated by means of number of indicators. The key factors of influence are:

- political environment 
- business and innovation environment;

- infrastructure

- accessibility

- skills

- personal use of technology;

- use of technologies by the business sector;

- use of technologies by the public sector;

- the impact of technology on the economy;

- the impact of technology on the society.

3) To estimate communications (networks), we offer the use of the ICT Development index. It evaluates the development of communications in three areas: access, use, skills. The key factors of influence are:

- The number of people using landline phones;

- The number of people using mobile phones;

- Internet usage in bits per person;

- The number of households with computers;

- The number of households with Internet access;

- The number of people using the Internet;

- The number of people using the cable Internet;

- the number of people using the mobile Internet;

- the average number of education years;

- the total number of people receiving second level education;

- the total number of people receiving third level education.

4) To estimate the state, we offer to use the DB (Ease of Doing Business Index) as an indicator of the quality of the environment in which the process of creating and distributing an intellectual product takes place. The key factors of influence are:

- procedures, time, costs and minimum capital for the establishment of an enterprise;

- work with building permits;

- receiving electricity; 
- property registration;

- obtaining a loan;

- protection of investors' rights;

- payment of taxes;

- international trade;

- provision of contracts;

- closing an enterprise.

5) Separately, we offer to take into account the Sustainable Development Goals Index (SDGI), in order to assess the country's development in the context of sustainability (environmental and social justice of economic development). This index assesses the implementation of 17 main goals of sustainable development: poverty and hunger overcoming, agricultural development, good health, quality education, gender equality, clean water and proper sanitation, affordable and clean energy, decent work and economic growth, industry, innovation and infrastructure, reduction of inequality, sustainable urban development, responsible consumption and production, mitigation the effects of climate change, the conservation of marine resources, the protection and restoration of land ecosystems, peace, justice and strong institutions, partnership for sustainable development.

Based on the foregoing, the condition of the world's intellectual economy can be estimated by the five indices that we offer to bring to one - the integral index of the intellectual economy. We offer to illustrate an assessment of some formation centers of the structure of the world's intellectual economy on the data of the following countries of the world: the USA - as one of the most powerful centers of the modern world, Japan - as a country that has primacy in the use and formation of intellectual product, China and India - as new economies that are developing rapidly and becoming new powerful centers of the world, Russia as the personification of the «Eastern Partnership» for the future development of Ukraine, Poland - as the embodiment of the European vector of development of Ukraine and directly Ukraine. Table 1 presents data for five aggregated indices; each index is represented by the latest actual data from its calculation.

As we see, India is the outsider from the selected countries for all indices, in turn the leader in almost all indicators is the United States, and Japan is the only leader in the Information and Communication Technology Index.

In order to reduce this data into one index of the intellectual economy, it is necessary to introduce the initial data of each index in single information coordinates. 
Table 1

International Indices for a selected group of countries

\begin{tabular}{|l|c|c|c|c|c|}
\hline \multicolumn{1}{|c|}{ Country } & HDI 2017 & NRI 2016 & ICT 2017 & DB 2018 & SDGI 2018 \\
\hline Ukraine & 0,751 & 4,2 & 5,62 & 65,75 & 72,3 \\
\hline Poland & 0,865 & 4,5 & 6,89 & 77,3 & 73,3 \\
\hline Russia & 0,816 & 4,5 & 7,07 & 75,5 & 68,9 \\
\hline USA & 0,924 & 5,8 & 8,18 & 82,54 & 73 \\
\hline Japan & 0,909 & 5,6 & 8,43 & 75,68 & 78,5 \\
\hline China & 0,752 & 4,2 & 5,6 & 65,29 & 70,1 \\
\hline India & 0,64 & 3,8 & 3,03 & 60,76 & 59,1 \\
\hline Average value & 0,81 & 4,66 & 6,40 & 71,83 & 70,74 \\
\hline
\end{tabular}

Source: Built by the authors on the basis of: (11), (12), (19), (23), (24).

To do this, we apply the method of relation to the average by the following formula:

$$
X_{i j}^{1}=\frac{x_{i j}^{1}}{P_{j}^{1}}
$$

$X_{i j}^{1}$ - standardized $i-1^{\text {st }}$ indicator $j$-country;

$x_{i j}^{1}-i-1^{\text {st }}$ indicator $j$-country;

$P_{j}^{1}$ - the average value of the $1^{\text {st }}$ indicator.

Table 2 illustrates received calculations, all the output data of the indexes are reduced to single information coordinates. The result is talking about the following - if the rate is less than 1 , it means that the index value is less than the average for the group, if more than 1 so the index value is above the average for the group.

Analyzing the data, we can conclude that the leaders of the above group are the United States and Japan. Performance of all indices of these countries is higher than the average for the group. In order to have a better understanding of the development of these countries, we propose to reduce the data into a single index, using the method of weighting coefficients. Experts who were involved in the definition of these indexes found human capital as the key factor in the intellectual economy structure. Because human capital generates new knowledge, new information and new intellectual products. Information systems and communications also have significant role. Even if there is a strong human potential, but 
the absence of an advanced IT-system and communication presence, it is impossible to create and distribute an intellectual product. Therefore, the weight of the coefficients was determined as follows: $\mathrm{HDI}-0,3, \mathrm{NRI}-0,2$, ICT -0,2, DB 0,15 , SDGI $-0,15$ (average values of expert evaluation data).

Table 2

International indices that are built into a single system of information coordinates for a selected group of countries

\begin{tabular}{|l|c|c|c|c|c|}
\hline \multicolumn{1}{|c|}{ Country } & HDI 2017 & NRI 2016 & ICT 2017 & DB 2018 & SDGI 2018 \\
\hline Ukraine & 0,93 & 0,90 & 0,88 & 0,92 & 1,02 \\
\hline Poland & 1,07 & 0,97 & 1,08 & 1,08 & 1,04 \\
\hline Russia & 1,01 & 0,97 & 1,10 & 1,05 & 0,97 \\
\hline USA & 1,14 & 1,24 & 1,28 & 1,15 & 1,03 \\
\hline Japan & 1,12 & 1,20 & 1,32 & 1,05 & 1,11 \\
\hline China & 0,93 & 0,90 & 0,88 & 0,91 & 0,99 \\
\hline India & 0,79 & 0,82 & 0,47 & 0,85 & 0,84 \\
\hline
\end{tabular}

Source: Built by the authors.

To evaluate the condition of the intellectual economy, we offer to use the Intellectual Economy Index (IEI) which is calculated by weighting coefficients based on the data of sub-indices, which are reduced to a single coordinate system using the following formula:

$$
I E I=0,3 \cdot H D I^{1}+0,2 \cdot N R I^{1}+0,2 \cdot I C T^{1}+0,15 \cdot D B^{1}+0,15 \cdot S D G I^{1},
$$

IEI - integral index of the intellectual economy;

$H D I^{1}$ - the standardized index of $\mathrm{HDI}$;

$N R I^{1}$ - the standardized index of NRI;

$I C T^{1}$ - the standardized index of ICT;

$D B^{1}$ - the standardized index of $\mathrm{DB}$;

$S D G I^{1}$ - the standardized index of SDGI.

The calculations are given in Table. 3. 
Table 3

The Intellectual Economy Index for a selected group of countries.

\begin{tabular}{|c|c|}
\hline Country & IEI \\
\hline Ukraine & 0,92 \\
\hline Poland & 1,05 \\
\hline Russia & 1,02 \\
\hline USA & 1,17 \\
\hline Japan & 1,16 \\
\hline China & 0,92 \\
\hline India & 0,75 \\
\hline Average value & 0,999 \\
\hline
\end{tabular}

Source: Built by the authors.

Thus, according to the data of the Intellectual Economy Index for the selected group of countries, we can enter the following grading score: value that is greater than 1, demonstrates a highly intellectual structure of the economy that has a strong human capital, a developed field of IT technologies and communications and also has a favorable environment for doing business and fulfills the goals of sustainable development. This value is greater than the average for the group. Values less than 1 exhibit underdeveloped structure of the intellectual economy. Consequently, the changes in the country are necessary in order to ensure the formation and development of a modern economic system. The United States, Japan, Poland and Russia are the leaders among the countries of the selected group on the Intellectual Economy Index. In our opinion, the use of the proposed index for these countries will provide an opportunity to estimate the condition of the intellectual economy on the basis of comparative methodology. At the same time, it includes factors that influence on each participant of the system. Thus, by understanding the influence of the factors presented by the constituent international indexes, we can come to an understanding of the elements essence of the system of the world's intellectual economy itself.

As noted above, such system consists of 4 main units: labor force, modern technology, communication network and state. Each of them is characterized by certain features, which are expressed through the factors of influence on each participant that are defined through international indices. The direction of each participant's activity has an impact on sustainable development, which is evaluated with the help of an additional index. The key factor of this system is knowledge that is generated by labor, characterized by a high level of education, knowledge, the availability of certain individual skills and abilities that distinguish the workforce involved in the production of intellectual product. Drivers of the in- 
tellectual economy system are the IT sphere and the field of communications. The system regulator is the state, which forms a favorable environment for the development of economic processes and protects the created intellectual product.

\section{Conclusion}

The modern world intellectual economy is in a constant process of development; therefore, the analysis of its condition is becoming an actual task of the present. We believe that the intellectual economy is a system that has knowledge of as its basis as the outcome of its activities. At the same time, the amount of information is constantly increasing, so the obvious task is to sort out and separate a part that will be a resource in the structure of the intellectual economy, and this task relies on the participant of the structure - the work force. Therefore, in the structure of the modern intellectual economy of the world the labor force should be considered as the main participant, and the main resource - knowledge or information. So, first of all, it is necessary to strengthen the human intellectual capital and contribute to creating the conditions for its fullest implementation. We propose to assess the condition of the intellectual economy of the world with the help of an integral Intellectual Economy Index (IEI). The evaluation of each sub index parameter, that influences the formation of the system and demonstrates its functioning and weaknesses. It gives a ground to form the strategy of developing the international competitiveness of the intellectual economies of individual countries, which collectively form the global intellectual economy.

Mentioned items need further research: the characteristics of each participant in the structure of the economic system, estimation of the index dynamics of the intellectual economy and trends forecasting, the study of the economy fields that embody the sphere of knowledge and are derived from the participants' interaction in the intellectual economy. All these issues are the basis for searching weaknesses in the national economy. On the experience of the leading countries it is necessary to construct elimination strategy of problematic structures, replace them with new, advanced one that will not be just an echo of the old economic structures and will be a part of a new global system of intellectual economy.

\section{References}

1. Abramowitz, M. (1956). Resource and output trends in the United States since 1870. American Economic Review. 5-23. 
2. Androshuk, G. A. (2006). Forecasting of innovation on the basis of the global firm's activity analysis. Problemy nauky, 5, 40-47 (in Russian).

3. AREC (2000). Towards knowledge-based economies in APEC. Singapore: AREC Secretariat.

4. Azhazha, M. A. (2007). Investing in education as a factor of intellectual progress. Social'na perspektyva i regional'nyj rozvytok, 2, 37-40 (in Ukrainian).

5. Brinkley, I. (2006). Defining the knowledge economy. London: The Work Foundation.

6. Chartland, H. H. (2006). The competitiveness of nations in a global knowledge-based economy (Unpublished doctoral thesis). University of Saskatchewan. Saskatchewan, Canada.

7. Drucker, P. (1950). The New Society: The anatomy of the industrial order. New York, NY: Harper \& Brothers.

8. Fedulova, L. I. (2009). Knowledge economy. NAS of Ukraine. Kyiv (in Ukrainian).

9. Gaponenko, A. L. (2010). Modern knowledge market: concept, participants, forms. Problemy teorii i praktiki upravlenija, 6, 55-64 (in Russian).

10. Huggins, R., Izushi, H., Prokop, D., and Thompson, P. (2014). Regional competitiveness, economic growth and stages of development. Zbornik Radova Ekonomskog Fakulteta u Rijeci, 32(2), 255-283.

11. Human Development Index. (2018). Retrieved from: http://hdr.undp.org/en/ countries

12. ITU. (2017). ICT Development Index. Retrieved from: http://www.itu.int/net4/ ITU-D/idi/2017/index.html\#idi2017rank-tab

13. Ivanova, V. V. (2011). Knowledge-based economy and knowledge economy: adequacy of using categories. Mehanizm reguljuvannja ekonomiky, 3, 47-54 (in Ukrainian)

14. Machlup, F. (1962). The Production and Distribution of Knowledge in the United Sttates. Princeton, N.J.: Princeton University Press.

15. Marshall, A. (1890). Principles of Economics. Eighth edition. London: Macmillan and Co., Ltd. 115.

16. OECD. (1996). The Knowledge-Based Economy. Paris: Organisation for Economic Cooperation and Development.

17. Romer, P. M. (1986). Increasing returns and long-run growth. Journal of Political Economy, 94(5).1002-1037.

18. Schumpeter, J. (1911). The Theory of Economic Development. Oxford: Oxford University Press. 57. 
19. SDG Index and Dashboards Report. (2018). Retrieved from: http://sdgindex.org/assets/files/2018/01\%20SDGS\%20GLOBAL\%20EDITIO N\%20WEB\%20V9\%20180718.pdf.

20. Shahrazad, H. (2017). Knowledge Economy: Characteristics and Dimensions. Management Dynamics in the Knowledge Economy. Vol. 5, 2, 203225.

21. Skilbeck, M. (1964). Study Group in the Economics of Education, Residual Factor and Economic Growth. Paris: Organisation for Economic Cooperation and Development.

22. Tapscott, D. (2014). The digital economy. Anniversary Edition: Rethinking promise and peril in the age of. networked intelligence. New York: McGrawHill.

23. WB. (2018). Doing Busines. Reforming to create jobs. Retrieved from: http://www.doingbusiness.org/content/dam/doingBusiness/media/AnnualReports/English/DB2018-Full-Report.pdf

24. WEF. (2016). The Networked Readiness Index report. Retrieved from: http://www3.weforum.org/docs/GITR2016/WEF_GITR_Chapter1.1_2016.pdf

25. White, D. S., Gunasekaran, A., and Ariguzo, G. (2012). The structural components of a knowledge-based economy. International Journal of Business Innovation and Research, 7(4), 504-518.

26. World Commission on Environment and Development. (1987). Our common future. Oxford: Oxford University Press. 